\title{
Commentary \\ An international initiative to identify genetic modifiers of cancer risk in BRCA1 and BRCA2 mutation carriers: the Consortium of Investigators of Modifiers of BRCA1 and BRCA2 (CIMBA)
}

\author{
Georgia Chenevix-Trench 1 , Roger L Milne², Antonis C Antoniou³, Fergus J Couch ${ }^{4}$, \\ Douglas F Easton ${ }^{3}$ and David E Goldgar ${ }^{5}$, on behalf of CIMBA
}

\author{
${ }^{1}$ Queensland Institute for Medical Research, Brisbane, Australia \\ ${ }^{2}$ Human Cancer Genetics Program, Spanish National Cancer Centre (CNIO), Madrid, Spain \\ ${ }^{3} \mathrm{CR}$-UK Genetic Epidemiology Unit, University of Cambridge, Cambridge, UK \\ ${ }^{4}$ Mayo Clinic College of Medicine, Rochester, Minnesota, USA \\ ${ }^{5}$ Department of Dermatology, University of Utah, Salt Lake City, Utah, USA
}

Corresponding author: Georgia Chenevix-Trench, georgiaT@qimr.edu.au

Published: 19 April 2007

This article is online at http://breast-cancer-research.com/content/9/2/104

(c) 2007 BioMed Central Ltd
Breast Cancer Research 2007, 9:104 (doi:10.1186/bcr1670)

estimated an average risk by age 70 in this context of $66 \%$ in $B R C A 1$ carriers and $45 \%$ in BRCA2 carriers [3]. It has also been reported that cancer risks vary by the age at diagnosis and the type of cancer in the index case $[3,4]$. Such observations are consistent with the more plausible hypothesis that cancer risks in mutation carriers are modified by genetic factors or other risk factors that cluster in families. Segregation analysis has also demonstrated that models that allow for other genes to have a modifying effect on the breast cancer risks conferred by $B R C A 1$ and $B R C A 2$ mutations fit significantly better than models without a modifying component [5]. Further evidence for genetic modifiers arises from studies of risk factors that are themselves influenced by genetic factors. For example, mammographic density that has a strong genetic component [6] has been recently shown in one study to modify the breast cancer risks in BRCA1 and BRCA2 mutation carriers [7].

Although there has been considerable interest in finding genetic modifiers of cancer risk in BRCA1 and BRCA2 mutation carriers, the number of published studies is still fairly modest and has focused around genes involved in a limited number of pathways: detoxification of environmental carcinogens, DNA repair and steroidogenesis. Several studies have evaluated the CAG repeat length polymorphism in the androgen receptor $(A R)$ gene as a modifier of breast cancer risk among mutation carriers. However, the data from different studies are contradictory and no firm conclusions can be drawn as to the magnitude of such an effect, if any [8-11]. Many studies have also evaluated a repeat length polymorphism in $A / B 1$ as a modifier of risk among BRCA1 or 
BRCA2 mutation carriers. Although an effect of high numbers of repeats on cancer risk in carriers was first reported by Rebbeck and colleagues [12], three large subsequent studies failed to replicate this result [13-15]. RAD51 currently provides the most convincing evidence for the existence of a modifier gene, at least for BRCA2 mutation carriers. LevyLahad and colleagues [16] first reported that the $-135 \mathrm{G}>\mathrm{C}$ single nucleotide polymorphism (SNP) in the $5^{\prime}$ untranslated region of RAD51 modified the breast cancer risk in BRCA2 carriers and this finding has been substantiated by others $[17,18]$. The function of the $-135 \mathrm{G}>\mathrm{C}$ SNP in RAD51 is not clear, but it could affect mRNA stability or translational efficiency.

Choosing candidate SNPs or genes to evaluate as modifiers of $B R C A 1$ and BRCA2 suffers from the same problem faced by all candidate-based genetic association studies, namely the poor understanding of the relevant pathways and hence the small a priori likelihood that any of them are true modifiers [19]. These issues may be overcome in the future through the identification of candidate genomic regions associated with breast cancer risk by linkage analyses [20], or more plausibly by the identification of candidate SNPs by adequately powered genome-wide association studies [21]. In addition, the publication of convincingly validated SNPs associated with breast cancer in the general population [22] will provide some new candidates to test as modifiers of breast cancer risk among BRCA1 or BRCA2 mutation carriers. However, since SNPs associated with breast cancer in the general population may not act in the same way among BRCA1 and $B R C A 2$ mutation carriers, pathway-based and perhaps genome-wide association studies in BRCA1 and BRCA2 carriers are also needed.

\section{Consortium of Investigators of Modifiers of BRCA1 and BRCA2 (CIMBA)}

A number of large studies and consortia have been established that aim to identify genetic modifiers of cancer risk in BRCA1 and BRCA2 mutation carriers, including Modifiers and Genetics in Cancer (MAGIC), Epidemiological study of BRCA1 and BRCA2 mutation carriers (EMBRACE), Genetic Modifiers of cancer risk in BRCA1/2 mutation carriers (GEMO), the Kathleen Cuningham Consortium for Research into Familial Breast Cancer (kConFab), the German Consortium for Hereditary Breast and Ovarian Cancer (GCHBOC) and the Breast Cooperative Family Registry (Breast-CFR). However, with current sample sizes of less than 1,500 carriers, none of these groups have adequate power to identify genetic modifiers with confidence. To address this problem, a 'consortium of consortia', the Consortium of Investigators of Modifiers of BRCA1 and BRCA2 (CIMBA), was established in 2005 (see Additional file 1 for a list of current contributors). The operating principles of CIMBA are: CIMBA is open to any group that can contribute genotypic and basic phenotypic and epidemiological risk factor data from at least 100 female
$B R C A 1$ and BRCA2 mutation carriers with or without a cancer diagnosis - groups with smaller collections of carriers are encouraged to participate through partnership with a larger group; panels of SNPs for genotyping are selected at face-to-face meetings every six months; only SNPs that show significant associations (arbitrarily set at $p<0.01$ ) with breast cancer risk in carriers, either in the published literature or in data from a member group, or are convincingly identified as associated with breast cancer in the general population, are considered; each group is free to participate, or not, in any round of genotyping; genotyping quality control standards must be followed $>2 \%$ duplicates, call rates $>95 \%$, notemplate controls on every plate and randomized arrangement of affected and unaffected carriers for genotyping); all epidemiological risk factor data and genotyping data from carriers are submitted to the CIMBA data coordinating centre at the University of Cambridge; and genotyping data from participating centers are pooled for analysis. There are currently about 30 groups from North America, Europe and Australia who plan to contribute to some or all of the collaborative CIMBA projects, and collectively they have DNA and minimum required clinical and epidemiological data from more than 10,000 BRCA1 and 5,000 BRCA2 carriers.

\section{Statistical considerations}

Most association studies are case-control studies, in which genotype frequencies in a series of cases are compared with those in series of controls. The analysis of BRCA1 and $B R C A 2$ modifiers is potentially more complex, because a high proportion of carriers become affected. Thus, modifiers would be expected to influence not just whether a carrier became affected but also the age at diagnosis. More powerful analyses can, therefore, be conducted by treating breast cancer as a survival (age at onset) rather than a simple binary endpoint. An additional problem, however, is introduced by the fact that mutation carriers are mainly ascertained through cancer genetics clinics. In these settings, the first tested individual in a family is usually someone diagnosed with cancer at a relatively young age. Such study designs tend, therefore, to lead to an oversampling of affected individuals and standard analytical methods like Cox regression may lead to biased estimates of the risk ratios [5]. CIMBA aims to address this potential bias by using standard analytical methods, such as weighted Cox regression, or by analyzing the data within a retrospective likelihood framework [5]. In addition, analyses restricted to incident cases, defined as carriers diagnosed with cancer no more than five years prior to ascertainment, are applied to account in part for ascertainment and possible survival bias. One of the aims of CIMBA is also to further develop the statistical methodology used to analyze such data. Among BRCA1 mutation carriers and at a threshold of $p<0.0001$, CIMBA currently has a power of over $80 \%$ to detect polymorphisms with minor allele frequencies greater than $10 \%$ that confer risk ratios in excess of 1.2 (Table 1). The power is somewhat lower among the current sample of 
Table 1

\begin{tabular}{lccc}
\multicolumn{4}{l}{$\begin{array}{l}\text { Simulated power (\%) to detect a polymorphism with varying } \\
\text { minor allele frequency and risk ratio, under a multiplicative } \\
\text { model at a significance level }\end{array}$} \\
\hline $\begin{array}{l}\text { Minor allele } \\
\text { frequency }\end{array}$ & $\begin{array}{c}\text { Relative } \\
\text { hazard }\end{array}$ & $\begin{array}{c}\text { Sample size: } \\
5000\end{array}$ & $\begin{array}{c}\text { Sample size: } \\
10,000\end{array}$ \\
\hline 0.10 & 1.1 & 2 & 7 \\
& 1.2 & 33 & 80 \\
0.20 & 1.3 & 86 & 100 \\
& 1.1 & 5 & 26 \\
0.30 & 1.2 & 74 & 100 \\
& 1.3 & 100 & 100 \\
& 1.1 & 10 & 44 \\
& 1.2 & 89 & 100 \\
\hline
\end{tabular}

Simulations performed as in [5].

BRCA2 mutation carriers. However, it is still far greater than the power that be achieved by each study individually - at a minor allele frequency of $20 \%$ and risk ratio of 1.2 , the corresponding power would be $<5 \%$ for a sample size of approximately 1,000 carriers. Moreover, most of the participating CIMBA centers are actively recruiting carriers, and larger sample sizes are expected in the future.

\section{Conclusions}

The identification of convincingly validated modifiers of breast cancer risk for BRCA1 and BRCA2 mutation carriers will help to understand the biology of hereditary breast tumors and, in the case of BRCA1-mutation-associated risk modifiers, will also provide candidate low penetrance genes for 'sporadic' basal cell breast cancers because of their similarity to $B R C A 1$-related breast tumors $[23,24]$. In the long term it might be possible to include information on genetic modifiers in risk prediction models, to give individualized advice to mutation carriers on individual breast cancer risks, and to have sufficient power to evaluate the risk of other cancers in BRCA1 and BRCA2 mutation carriers.

\section{Additional file}

The following Additional file is available online:

\section{Additional file 1}

Current contributors to CIMBA.

See http://breast-cancer-research.com/content/

supplementary/bcr1670-s1.doc

\section{Competing interests}

The authors declare that they have no competing interests.

\section{Acknowledgements}

Statistical and data management support for CIMBA, and support for EMBRACE and A Antoniou, are provided by Cancer Research UK. The MAGIC Consortium is supported by US Public Health Service grants R01-CA102776, R01-CA08574 and P50-CA83638; EMBRACE by a Cancer Research-UK grant to DF Easton; kConFab by grants from the National Breast Cancer Foundation, the National Health and Medical Research Council (NHMRC, including grants 145684 and 288704) and by the Queensland Cancer Fund, the Cancer Councils of New South Wales, Victoria, Tasmania and South Australia, and the Cancer Foundation of Western Australia; INHERIT by the Canadian Institutes of Health Research, and by the Canada Research Chair in Oncogenetics (J Simard); DNA-HEBON Study Netherlands by a grant from the Dutch Cancer Society, NKI 2007-3756; OCGN by Cancer Care Ontario, and OCGN and Susan Neuhausen and Saundra Buys through cooperative agreements with the Northern California Cancer Center, Cancer Care Ontario, The University of Melbourne, Fox Chase Cancer Center, Columbia University and the Huntsman Cancer Institute as part of the Breast Cancer Family Registry (Breast CFR) funded under RFA\#CA-95-003; the Helsinki Breast Cancer Study by the Academy of Finland (110663), Finnish Cancer Society, Helsinki University Central Hospital Research Fund and the Sigrid Juselius Fund; the GEMO study by the Programme Hospitalier de Recherche Clinique AOR01082, by Programme Incitatif et Coopératif Génétique et Biologie de Cancer du Sein, Instutut Curie, and by the Association "Le cancer du sein, parlons-en!" Award; The GCHBOC by the German Cancer Aid (grant 107054) and the Center for Molecular Medicine Cologne (grant TV 93 to Rita Schmutzler).

G Chenevix-Trench and A Spurdle and supported by grants from the National Health and Medical Research Council of Australia; FJ Couch by grants from the Breast Cancer Research Foundation (BCRF), US Army Medical Research and Materiel Command (W81XWH-04-10588) and the Mayo Clinic Breast Cancer SPORE (P50-CA116201); $\mathrm{K}$ Nathanson by a grant from the Breast Cancer Research Foundation; C Szabo by the Susan G Komen Breast Cancer Foundation (BCTR0402923); M Zikan, P Pohlreich and Z Kleibel by the Research Project of the Ministry of Education, Youth and Sports of the Czech Republic (MSM0021620808); J Struewing in part by the Intramural Research Program of the $\mathrm{NIH}$, Division of Cancer Epidemiology and Genetics and the Center for Cancer Research, National Cancer Institute, US Department of Health and Human Services.

\section{References}

1. Ford D, Easton DF, Stratton M, Narod S, Goldgar D, Devilee P, Bishop DT, Weber B, Lenoir G, Chang-Claude J, et al:: Genetic heterogeneity and penetrance analysis of the BRCA1 and BRCA2 genes in breast cancer families. The Breast Cancer Linkage Consortium. Am J Hum Genet 1998, 62:676-689.

2. Easton DF, Ford D, Bishop DT: Breast and ovarian cancer incidence in BRCA1-mutation carriers. Breast Cancer Linkage Consortium. Am J Hum Genet 1995, 56:265-271.

3. Antoniou A, Pharoah PD, Narod S, Risch HA, Eyfjord JE, Hopper $\mathrm{JL}$, Loman $\mathrm{N}$, Olsson $\mathrm{H}$, Johannsson $\mathrm{O}$, Borg $\mathrm{A}$, et al:: Average risks of breast and ovarian cancer associated with BRCA1 or BRCA2 mutations detected in case series unselected for family history: a combined analysis of 22 studies. Am J Hum Genet 2003, 72:1117-1130.

4. Simchoni S, Friedman E, Kaufman B, Gershoni-Baruch R, OrrUrtreger A, Kedar-Barnes I, Shiri-Sverdlov R, Dagan E, Tsabari S, Shohat $M$, et al.: Familial clustering of site-specific cancer risks associated with BRCA1 and BRCA2 mutations in the Ashkenazi Jewish population. Proc Natl Acad Sci USA 2006, 103:3770-3774.

5. Antoniou AC, Goldgar DE, Andrieu N, Chang-Claude J, Brohet R, Rookus MA, Easton DF: A weighted cohort approach for analysing factors modifying disease risks in carriers of highrisk susceptibility genes. Genet Epidemio/ 2005, 29:1-11.

6. Boyd NF, Dite GS, Stone J, Gunasekara A, English DR, McCredie MR, Giles GG, Tritchler D, Chiarelli A, Yaffe MJ, et al.: Heritability of mammographic density, a risk factor for breast cancer. $N$ Engl J Med 2002, 347:886-894.

7. Mitchell G, Antoniou AC, Warren R, Peock S, Brown J, Davies R, Mattison J, Cook M, Warsi I, Evans DG, et al.: Mammographic density and breast cancer risk in BRCA1 and BRCA2 mutation carriers. Cancer Res 2006, 66:1866-1872. 
8. Dagan E, Friedman E, Paperna T, Carmi N, Gershoni-Baruch R: Androgen receptor CAG repeat length in Jewish Israeli women who are BRCA1/2 mutation carriers: association with breast/ ovarian cancer phenotype. Eur J Hum Genet 2002, 10:724-728.

9. Kadouri L, Easton DF, Edwards S, Hubert A, Kote-Jarai Z, Glaser B, Durocher F, Abeliovich D, Peretz T, Eeles RA: CAG and GGC repeat polymorphisms in the androgen receptor gene and breast cancer susceptibility in BRCA1/2 carriers and non-carriers. Br J Cancer 2001, 85:36-40.

10. Rebbeck TR, Kantoff PW, Krithivas K, Neuhausen S, Blackwood MA, Godwin AK, Daly MB, Narod SA, Garber JE, Lynch HT, et al.: Modification of BRCA1-associated breast cancer risk by the polymorphic androgen-receptor CAG repeat. Am J Hum Genet 1999, 64:1371-1377.

11. Spurdle AB, Antoniou AC, Duffy DL, Pandeya N, Kelemen L, Chen $X$, Peock S, Cook MR, Smith PL, Purdie DM, et al.: The androgen receptor CAG repeat polymorphism and modification of breast cancer risk in BRCA1 and BRCA2 mutation carriers. Breast Cancer Res 2005, 7:R176-183.

12. Rebbeck TR, Wang Y, Kantoff PW, Krithivas K, Neuhausen SL, Godwin AK, Daly MB, Narod SA, Brunet JS, Vesprini D, et al:: Modification of BRCA1- and BRCA2-associated breast cancer risk by AIB1 genotype and reproductive history. Cancer Res 2001, 61:5420-5424.

13. Hughes DJ, Ginolhac SM, Coupier I, Barjhoux L, Gaborieau V, Bressac-de-Paillerets B, Chompret A, Bignon YJ, Uhrhammer N, Lasset $\mathrm{C}$, et al.: Breast cancer risk in BRCA1 and BRCA2 mutation carriers and polyglutamine repeat length in the AIB1 gene. Int J Cancer 2005, 117:230-233.

14. Kadouri L, Kote-Jarai Z, Easton DF, Hubert A, Hamoudi R, Glaser B, Abeliovich D, Peretz T, Eeles RA: Polyglutamine repeat length in the AIB1 gene modifies breast cancer susceptibility in BRCA1 carriers. Int J Cancer 2004, 108:399-403.

15. Spurdle AB, Antoniou AC, Kelemen L, Holland H, Peock S, Cook MR, Smith PL, Greene MH, Simard J, Plourde M, et al.: The AIB1 polyglutamine repeat does not modify breast cancer risk in BRCA1 and BRCA2 mutation carriers. Cancer Epidemiol Biomarkers Prev 2006, 15:76-79.

16. Levy-Lahad E, Lahad A, Eisenberg S, Dagan E, Paperna T, Kasinetz L, Catane R, Kaufman B, Beller U, Renbaum P, et al.: A single nucleotide polymorphism in the RAD51 gene modifies cancer risk in BRCA2 but not BRCA1 carriers. Proc Natl Acad Sci USA 2001, 98:3232-3236.

17. Kadouri L, Kote-Jarai Z, Hubert A, Durocher F, Abeliovich D, Glaser B, Hamburger T, Eeles RA, Peretz T: A single-nucleotide polymorphism in the RAD51 gene modifies breast cancer risk in BRCA2 carriers, but not in BRCA1 carriers or noncarriers. $\mathrm{Br}$ $J$ Cancer 2004, 90:2002-2005.

18. Wang WW, Spurdle AB, Kolachana $P$, Bove B, Modan B, Ebbers SM, Suthers G, Tucker MA, Kaufman DJ, Doody MM, et al:: A single nucleotide polymorphism in the $5^{\prime}$ untranslated region of RAD51 and risk of cancer among BRCA1/2 mutation carriers. Cancer Epidemiol Biomarkers Prev 2001, 10:955-960.

19. Pharoah PD, Dunning AM, Ponder BA, Easton DF: Association studies for finding cancer-susceptibility genetic variants. Nat Rev Cancer 2004, 4:850-860.

20. Nathanson KL, Shugart YY, Omaruddin R, Szabo C, Goldgar D, Rebbeck TR, Weber BL: CGH-targeted linkage analysis reveals a possible BRCA1 modifier locus on chromosome 5q. Hum Mol Genet 2002, 11:1327-1332.

21. Hirschhorn JN, Daly MJ: Genome-wide association studies for common diseases and complex traits. Nat Rev Genet 2005, 6: 95-108.

22. Cox A, Dunning AM, Garcia-Closas M, Balasubramanian S, Reed MW, Pooley KA, Scollen S, Baynes C, Ponder BA, Chanock S, et al:: A common coding variant in CASP8 is associated with breast cancer risk. Nat Genet 2007, 39:352-358.

23. Lakhani SR, Jacquemier J, Sloane JP, Gusterson BA, Anderson TJ, van de Vijver MJ, Farid LM, Venter D, Antoniou A, Storfer-Isser $\mathrm{A}$, et al.: Multifactorial analysis of differences between sporadic breast cancers and cancers involving BRCA1 and BRCA2 mutations. J Nat/ Cancer Inst 1998, 90:1138-1145.

24. Lakhani SR, Reis-Filho JS, Fulford L, Penault-Llorca F, van der Vijver M, Parry S, Bishop T, Benitez J, Rivas C, Bignon YJ, et al.: Prediction of BRCA1 status in patients with breast cancer using estrogen receptor and basal phenotype. Clin Cancer Res 2005, 11:5175-5180. 